\title{
PERLINDUNGAN HUKUM BAGI TENAGA KERJA DARI TINDAKAN PHK PERUSAHAAN DIMASA COVID-19
}

\section{LEGAL PROTECTION FOR LABOR FROM PHK FUNCTION MEASURES IN THE COVID-19 PERIOD}

\author{
Ramlan$^{1}$ dan Rizki Rahayu Fitri ${ }^{2}$ \\ ${ }^{1,2}$ Hukum, Fakultas Hukum, Universitas Muhammadiyah Sumatera Utara \\ Jln. Kapten Muchtar Basri No.3, Medan Timur, Glugur Darat II, Sumatera Utara, 20238 \\ Email: ramlan_mosya71@yahoo.com
}

\begin{abstract}
Covid-19 in Indonesia made the national economy worse, so the unemployment rate was booming, because company workers had to be dismissed because debtors were unable to pay their salaries. This forced situation is called force majeure, is a situation where the company is no longer able to pay workers' wages. The purpose of this study was to analyze the legal protection for workers from company layoffs. The author is interested in studying, who is the party that suffers losses due to Force Majeure conditions for workers during the Covid-19 pandemic? In this situation, company policy is needed, employee flexibility to be clear in dealing with this situation.
\end{abstract}

Keywords: Force majeure, labor, and company

\section{Intisari}

Covid-19 di Indonesia membuat perekonomian nasional memburuk, sehingga angka pengangguran kian membludak, sebab buruh perusahaan terpaksa diberhentikan karena debitur tidak sanggup membiayai gaji mereka. Keadaan terpaksa ini disebut dengan force majeure, merupakan keadaan dimana perusahaan tidak lagi mampu membayar upah pekerja. Tujuan penelitian ini untuk menganalisis perlindungan hukum bagi tenaga kerja dari tindakan PHK perusahaan. Penulis tertarik mengkaji, Siapakah Pihak yang menanggung kerugian karena keadaan Force Majeure terhadap pekerja pada masa pandemic Covid-19?, Bagaimana Perlindungan Hukum Terhadap Pekerja Atas Perjanjian Kerja Waktu Tertentu pada masa Covid-19?. Dalam situasi ini, diperlukan kebijaksanaan perusahaan, kelegowoan pekerja agar jernih dalam menyikapi situasi ini.

Kata kunci: Force majeure, buruh, dan perusahaan

\section{A. Pendahuluan}

Undang-Undang Dasar Negara Republik Indonesia (UUDNRI) Tahun 1945 Pasal 28D Ayat (2) yang dinyatakan, "Setiap orang berhak untuk bekerja serta mendapat imbalan dan perlakuan yang adil dan layak dalam hubungan kerja". ${ }^{3}$

\footnotetext{
${ }^{1}$ Dosen Fakultas Hukum Universitas Muhammadiyah Sumatera Utara.

${ }^{2}$ Mahasiswa Pasca Sarjana Universitas Sumatera Utara.

${ }^{3}$ Lihat Pasal 28 A Ayat (2) Undang-Undang Dasar Negara Republik Indonesia (UUD NRI) Tahun 1945.
} 
Terlepas dari adanya jaminan bagi setiap warga negara terkait hak untuk mendapatkan pekerjaan dan penghidupan yang layak, dalam dunia ketenagakerjaan merupakan salah satu masalah yang sering muncul yaitu Pemutusan Hubungan Kerja (PHK), selanjutnya disingkat dengan PHK, yang tidak jarang juga, dapat menimbulkan konflik hubungan industrial, konflik antara pengusaha dengan pekerja/buruh, yang mengakibatkan terjadinya pengangguran.

Pasal 1 Angka 25 Undang-Undang Nomor 13 tahun 2003 tentang Ketenagakerjaan memberikan definisi, "Pemutusan Hubungan Kerja adalah pengakhiran hubungan kerja karena suatu hal tertentu yang mengakibatkan berakhirnya hak dan kewajiban antara pekerja/ buruh dan pengusaha". ${ }^{4} \mathrm{PHK}$ adalah salah satu hal yang seharusnya dapat dihindarkan, baik itu oleh pengusaha atau pun oleh pekerja/ buruh. Namun hal ini masih sering terjadi, masih cukup sering ditemui adanya kasus-kasus Pemutusan Hubungan Kerja (PHK) yang dilakukan oleh beberapa perusahaan dengan berbagai alasan atau penyebabnya. Keputusan pemutusan hubungan kerja tentunya berdampak buruk terhadap perekonomian dan kelangsungan hidup serta masa depan para pekerja/buruh. Dalam hal terjadi pemutusan hubungan kerja, tentunya tidak boleh dilakukan secara sewenangwenang. Pemutusan hubungan kerja hanya boleh dilakukan karena alasan-alasan tertentu, setelah melalui beberapa tahapan upaya yang tentunya dilakukan untuk dapat menghindarinya.

Ditengah terjadinya permasalahan seperti covid-19 ini, yang menjadi korban dari force majeure ialah karyawan yang memiliki kontrak kerja tertentu. Sehingga ancaman PHK dan sebagainya lebih menonjol kepada karyawan yang hanya sebatas kerja tertentu. Namun beda halnya dengan karyawan yang bekerja memiliki waktu tidak tertertu. Perlu diketahui terlebih dahulu Perjanjian Kerja Waktu Tertentu (PKWT) adalah perjanjian kerja antara pekerja/buruh dengan pengusaha untuk mengadakan hubungan kerja dalam waktu tertentu. Penerapan sistem PKWT lebih banyak digunakan oleh perusahaan dinilai sangat efektif dan efisien bagi pengusaha yaitu demi mendapatkan keuntungan yang lebih besar dimana biaya dikeluarkan pengusaha untuk pekerjaan menjadi lebih kecil karena pengusaha tidak harus memiliki tenaga kerja/pekerja dalam jumlah yang banyak. Hubungan pengusaha dan tenaga kerja yang bekerja bersama-sama dalam menjalankan suatu kegiatan usaha dalam hukum ketenagakerjaan dikenal dengan istilah hubungan kerja, yaitu hubungan antara pengusaha dengan pekerja/buruh berdasarkan perjanjian kerja, yang mempunyai unsur pekerjaan, upah, dan perintah. Setiap hubungan kerja ini secara otomatis akan terikat dengan adanya hak dan kewajiban yang harus dilaksanakan oleh pengusaha dan pekerja sesuai dengan kesepakatan dalam perjanjian yang dibuatnya.

Pada tanggal 13 April 2020 lalu, Presiden Republik Indonesia merilis sebuah Keputusan Presiden (Keppres) tentang bencana non-alam yakni Keppres No. 12 Tahun 2020 tentang Penetapan Bencana Non-alam Penyebaran Corona Virus Disease 2019 (Covid-19) Sebagai Bencana Nasional. Sontak menyusul dirilisnya Perpres tersebut muncul spekulasi di tengah-tengah masyarakat bisnis bahwa Keppres tersebut bisa dijadikan dasar untuk membatalkan kontrak-kontrak

${ }^{4}$ Lihat Pasal 1 Angka 25 Undang-Undang Nomor 13 Tahun 2003 tentang Ketenagakerjaan. 
keperdataan, terutama kontrak-kontrak bisnis. Alasannya bencana adalah sebuah force majeure, kejadian luar biasa yang menyebabkan orang tidak mampu memenuhi prestasinya karena peristiwa yang di luar kemampuannya. Di dalam hukum perjanjian memang ada ketentuan bahwa force majeure bisa dijadikan alasan untuk membatalkan kontrak. Tetapi tentu saja spekulasi tersebut misleading yang agak meresahkan, bukan hanya dalam dunia usaha tetapi juga bagi Pemerintah. $^{5}$

Dalam praktik dunia ketenagakerjaan, sudah banyak perusahaan yang melakukan PHK, dengan berbagai alasan, dan sangatlah menarik untuk dapat diteliti, apakah alasan-alasan tersebut sudah sah jika ditinjau dari sisi hukum atau peraturan perundang-undangan yang berlaku. Undang-Undang Nomor 13 Tahun 2003 tentang Ketenagakerjaan sudah memberikan batasan-batasan terkait hal-hal yang diperbolehkan dan tidak diperbolehkan untuk dijadikan sebagai alasan atau pertimbangan untuk dilakukannya PHK. Tentang PHK diatur dalam Pasal 150 sampai dengan Pasal 172 Undang-Undang Nomor 13 Tahun 2003 tentang Ketenagakerjaan. PHK dilakukan oleh pengusaha terhadap pekerja atau buruh, dilakukan dengan berbagai alasan, seperti pengunduran diri, mangkir, perubahan status perusahaan, perusahaan tutup, perusahaan pailit, pekerja meninggal dunia, pekerja pensiun, atau karena pekerja/ buruh telah melakukan kesalahan berat, dan lain-lain.

Pasal 164 Ayat (3) Undang-Undang Nomor 13 Tahun 2003 tentang Ketenagakerjaan menyatakan: Pengusaha dapat melakukan pemutusan hubungan kerja terhadap pekerja/buruh karena perusahaan tutup bukan karena mengalami kerugian 2 (dua) tahun berturut-turut atau bukan karena keadaan memaksa (force majeure) tetapi perusahaan melakukan efisiensi, dengan ketentuan pekerja/ buruh berhak atas uang pesangon sebesar 2 (dua) kali, ketentuan Pasal 156 Ayat (2), uang penghargaan masa kerja sebesar 1 (satu) kali ketentuan Pasal 156 Ayat (3) dan uang penggantian hak sesuai ketentuan Pasal 156 Ayat (4).Keadaan memaksa adalah keadaan tidak dipenuhinya prestasi oleh debitur karena terjadi peristiwa yang tidak dapat diketahui atau tidak dapat diduga akan terjadi ketika membuat perikatan. Dalam keadaan memaksa, debitur tidak dapat disalahkan karena keadaan ini timbul di luar kemauan dan kemampuan debitur. ${ }^{6}$

Force majeure memang tidak bisa secara otomatis dijadikan alasan pembatalan kontrak ataupun PHK, tetapi memang bisa dijadikan pintu masuk untuk bernegosiasi dalam membatalkan atau mengubah isi kontrak. Kontrak harus tetap dilaksanakan sesuai dengan isinya karena menurut Pasal 1338 Kitab Undangundang Hukum Perdata (KUHPerd) "Setiap perjanjian yang dibuat secara sah berlaku sebagai undang-undang bagi yang membuatnya". Jadi selama kontrak tidak diubah dengan kontrak baru yang disepakati tetap berlaku mengikat seperti undangundang.

5 Asosiasi Pengajar Hukum Keperdataan,Bencana Covid-19 Dan Pembatalan Kontrak Dalam Bisnis, Perkembangan, Problematik, Dan Implikasi Force Majeure Akibat Covid-19 Bagi Dunia Bisnis" Seminar Nasional Keoordinator Kementeriah Hukum, Politik Dan Keamanan Republik Indonesia, Jakarta, hal 5

${ }^{6}$ Wawan Muhwan Hariri, 2011, Hukum Perikatan, Pustaka Setia, Bandung, hal 107 
Apabila diketahui pengusaha memiliki pekerja yang banyak, maka pengusaha harus memberikan berbagai tunjangan untuk kesejahteraan para pekerja seperti tunjangan pemeliharaan kesehatan, tunjangan pemutusan hubungan kerja (PHK), tunjangan penghargaan kerja dan sebagainya dalam arti kata mempekerjakan tenaga kerja dengan PKWT, maka biaya tersebut dapat ditekan. Akan tetapi, bagi pekerja kontrak sendiri mengenai kebijakan penggunaan dalam PKWT dinilai kurang menguntungkan karena mereka merasa tidak memiliki kepastian dalam hal jangka waktu kerja dalam pengangkatan sebagai karyawan tetap yang mempengaruhi jenjang karir, status atau kedudukan sebagai pekerja, dan pesangon pada saat kontrak akan berakhir. Namun faktanya pihak perusahaan dalam masa pandemic seperti ini malah merumahkan pekerja dan sekaligus memPHK pekerja, ini bukanlah solusi yang solutif untuk meningkatkan perekonomian Negara, yang ada peningkatan jumlah penduduk miskin sekaligus pengangguran massal. Sehingga krisis moneter pun terulang kembali.

Berdasarkan uraian pada latar belakang diatas penulis merumuskan permasalahan yang akan dikaji dalam penelitian ini, yaitu Pihak manakah yang menanggung kerugian karena keadaan Force Majeure terhadap pekerja pada masa pandemic covid-19? dan Bagaimana Perlindungan Hukum Terhadap Pekerja Atas Perjanjian Kerja Waktu Tertentu pada masa pandemic?

\section{B. PEMBAHASAN}

1. Pihak yang Menanggung Kerugian karena Keadaan Force Majeure terhadap Pekerja pada Masa Pandemic Covid-19

Dalam hal ganti kerugian yang ditanggung terhadap pekerja oleh perusahaan ialah:

a. Perjanjian hibah.

b. Perjanjian jual beli.

c. Perjanjian tukar menukar

d. Perjanjian sewa menyewa. ${ }^{7}$

Pihak-pihak bebas memperjanjikan tanggung jawab itu dalam perjanjian yang mereka buat apabila terjadi keadaan memaksa. Ganti rugi dalam keadaan memaksa hanya berlaku untuk ke empat hal diatas, namun dalam keadaan seperti covid-19 saat ini, tidak ada perusahaan baik juga pemerintah menanggung secara eksplisit kerugian yang di rasa oleh pekerja yang di PHK. Perjanjian kerja waktu tertentu yaitu perjanjian kerja antara pekerja/buruh dengan pengusaha yang hanya dibuat untuk pekerjaan tertentu yang menurut jenis dan sifat atau kegiatan pekerjaanya akan selesai dalam waktu tertentu. ${ }^{8}$ "Perjanjian kerja yang dibuat untuk waktu tertentu harus dibuat secara tertulis (Pasal 57 Ayat (1) Undang-Undang No.13 Tahun 2003 tentang Ketenagakerjaan). Ketentuan ini dimaksudkan untuk lebih menjamin atau menjaga hal-hal yang tidak diinginkan sehubungan dengan

7 Indrayani, Kajian Hukum Keterlambatan Membayar (Wanprestasi) Debitur DalamPerjanjian Sewa Beli Menurut Aturan Hukum Yang Berlaku, Lex Et Societatis Vol. VII/No. 10/Okt/2019, hal 43 hal. 59

${ }^{8}$ Abdul Khakim, 2007Hukum Ketenagakerjaan Indonesia, Pt. Citra Aditia Bakti, Bandung, 
berakhirnya kontrak kerja. Perjanjian kerja untuk waktu tertentu tidak boleh mensyaratkan adanya masa percobaan".

Setiap tenaga kerja berhak untuk mendapatkan upah yang layak sesuai dengan apa yang ditentukan oleh pemerintah. "Dalam Pasal 1 angka 30 UndangUndang No. 13 Tahun 2003 tentang Ketenagakerjaan, Berdasarkan pengaturan tersebut dapat kita ketahui bahwa upah ditetapkan dan dibayarkan menurut suatu perjanjian kerja, kesepakatan atau peraturan perundang-undangan".

Beberapa prinsip perjanjian kerja waktu tertentu yang perlu diperhatikan antara lain: Harus dibuat secara tertulis dalam bahasa Indonesia dan huruf latin, minimal rangkap dua; Apabila dibuat dalam Bahasa Indonesia dan bahasa asing dan terjadi perbedaan penafsiran, yang berlaku bahasa Indonesia; Hanya dapat dibuat untuk pekerjaan tertentu yang menurut jenis dan sifat atau kegiatan pekerjaanya akan selesai dalam waktu tertentu; Paling lama tiga tahun termasuk jika ada perpanjangan atau perbaharuan; Pembaharuan PKWT dilakukan setelah tenggang waktu tiga puluh hari sejak berakhirnya perjanjian; Tidak dapat diadakan untuk jenis pekerjaan yang bersifat tetap; Tidak dapat mensyaratkan adanya masa percobaan kerja dan Upah dan syarat kerja yang diperjanjikan tidak boleh bertentangan dengan peraturan perusahaan, perjanjian kerja bersama (PKB), dan perturan perundang-udangan. Apabila prinsip PKWT dilanggar: Terhadap hurup a sampai dengan huruf f, maka secara hukum PKWT menjadi PKWTT; Terhadap huruf $g$, maka tetap berlaku ketentuan dalam perauran perusahaan, perjanjian kerja bersama, dan peraturan perundang-undangan. ${ }^{9}$ Syarat-syarat pembuatan perjanjian kerja waktu tertentu.

Force Majeure adalah keadaan terpaksa atau kejadian yang terjadi diluar kemampuan manusia dan tidak dapat dihindarkan sehingga suatu kegiatan tidak dapat dilaksanakan sebagaimana mestinya. Force Majuere biasanya merujuk pada tindakan alam, sepertin bencana alam (banjir, gempa bumi), epidemic, kerusuhan, pernyataan perang, perang dan sebagainya. Pengertian bencana alam ialah suatu kejadian alam dikatakan sebagai bencana (disaster) apabila mengakibatkan korban dan penderitaan manusia, kerugian harta benda, kerusakan sarana, dan prasarana serta fasilitas umum yang menimbulkan gangguan terhadap tata kehidupan dan masyarakat. ${ }^{10}$

Dalam kaitan dengan kontrak pengadaan barang/jasa (kontrak pengadaan), lazimnya Force Majure dialami oleh penyedia (kontraktor/suuplier) baik karena bencana alam, bencana non alam, pemogokkan, barang diskontinyu, dll. Tetapi sekarang terjadi fenomena baru. Terjadinya pandemi mewajibkan negara untuk mengutamakan keselamatan penduduk, dan karena itu perlu menyediakan anggaran yang cukup. Inilah yang mengakibatkan terjadinya "pergeseran anggaran" yang kemudian membuat anggaran untuk pengadaan barang/jasa menjadi berkurang secara signifikan, atau bahkan tidak ada lagi. Di sisi lain, tentu pihak penyedia

${ }^{9}$ Ibid

${ }^{10}$ Dini Ajeng Wulandari, 2016, Wanprestasi Debitur Akibat Force Majeure (Bencana Alam) Dalam Perjanjian Kredit (Study Putusan Nomor: 25/Pdt.G/2010/Pn.Smi), Skripsi, Fakultas Hukum, Universitas Jember, hlm. 16. 
dalam banyak kasus juga mengalami kendala dalam memenuhi kewajibannya akibat pandemi ini. Banyak factor penyebab ${ }^{11}$

Konsep keadaan memaksa (Overmacht atau Force Majeur/FM) merupakan konsep yang terkait dengan pemenuhan kewajiban yang lahir dari perikatan (pemenuhan perikatan). Dua elemen fundamental dalam FM adalah: pemenuhan kewajiban tercegah, dan akibat tidak dipenuhinya kewajiban itu tidak dapat dipertanggungjawabkan kepada debitur (pihak yang wajib). Tercegah mengandung arti debitur tidak dapat melaksanakan kewajiban berhubung adanya peristiwa yang tergolong sebagai FM. Ini dapat seluruh atau sebagian kewajiban. Dan, dari segi waktu, dapat selamanya (permanent) dapat pula sementara (temporary). Makna tidak dapat dipertanggung jawabkan adalah bahwa debitur tidak dapat dituntut (digugat) untuk membayar ganti rugi, biaya atau pun bunga (Pasal 1244 jo. 1245. 1444 KUH Perdata). ${ }^{12}$

Sedangkan akibat dari kejadian yang sepertinya diluar kuasa manusia sehubungan dengan kegiatan ekonomi, misalnya krisis ekonomi Indonesia selama ini, yang mana ternyata menimbulkan efek yang berbeda pada pelaku ekonomi --maksudnya ada yang merugi dan memperoleh keuntungan --- biasanya bukan dasar alasan yang kuat sebagai force majeure. Dalam hal demikian, bagi pelaku yang merugi dapat meminta penyelesaian melalui mekanisme bi-partit dengan pihak terkait, atau bahkan meminta intervensi pemerintah, untuk keringanan/bantuan sehubungan dengan kerugiannya/tambahan beban kewajiban yang ditanggungnya. Mengenai PHK karena force majeure, UUK menetapkan bahwa pekerja/buruh berhak atas uang pesangon sebesar 1 (satu) kali ketentuan Pasal 156 (2) uang penghargaan masa kerja sebesar 1 (satu) kali ketentuan Pasal 156 (3) dan uang penggantian hak sesuai ketentuan Pasal 156.

\section{a. Akibat Hukum Force Majeure}

Jika ditelaah sifat force majeure memiliki implikasi yang sama yaitu ketidakmampuan salah satu pihak menjalankan kewajibannya. Sehingga implikasi yuridis dari tidak dijalankannya kewajiban, Pihak yang dirugikan dapat meminta ganti rugi yang dideritanya sebagai akibat dari tidak dijalankannya kewajiban salah satu pihak. Tetapi Mengacu pada Pasal 1244 j.o Pasal 1245 yang menyatakan sebagai berikut; Pasal 1244 KUHPerdata:

Jika ada alasan untuk itu si berhutang harus dihukum mengganti biaya, rugi dan bunga, bila ia tidak membuktikan, bahwa hal tidak dilaksanakan atau tidak pada waktu yang tepat dilaksanakannya perjanjian itu, disebabkan karena suatu hal yang tak terduga, pun tak dapat dipertanggungjawabkan padanya, kesemuanya itu pun jika itikad buruk tidak ada pada pihaknya.

${ }^{11}$ Y. Sogar Simamora, Force Majeur Dalam Kontrak Pengadaan Barang/Jasa Pemerintah, makalah seminar nasional, Guru Besar Fh Unair-Surabaya - Ketua Asosiasi Pengajar Hukum Keperdataan. Hlm. 10.

${ }^{12}$ Ibid. 
Pasal 1245 KUHPerdata: “

Tidaklah biaya, rugi dan bunga harus digantinya, apabila karena keadaan memaksa (overmacht) atau karena suatu keadaan yang tidak disengaja, si berutang berhalangan memberikan atau berbuat sesuatu yang diwajibkan, atau karena hal-hal yang sama telah melakukan perbuatan yang terlarang."

Sehingga dapat disimpulkan bahwa kedua Pasal diatas mengafirmasi untuk melepaskan kewajiban mengganti rugi bagi pihak yang tidak dapat menjalankan kewajibannya karena adanya keadaan memaksa/force majeure. Selain itu akibat hukum lainnya yang mungkin terjadi adalah melakukan perubahan/addendum perjanjian untuk menjalankan kewajiban di waktu lain jika disepakati oleh para pihak tergantung dari isi klausul perjanjian itu sendiri.

Adapun syarat-syarat formal yang harus dipenuhi oleh suatu kesepakatan kerja tertentu adalah sebagai berikut:

a) Kesepakatan kerja dibuat rangkap 3 (tiga), masing-masing digunakan untuk pekerja, pengusaha dan kantor Departemen Tenaga Kerja setempat yang masingmasing memiliki kekuatan hukum yang sama.

b) Kesepakatan kerja harus didaftarkan pada kantor Departemen Tenaga Kerja Setempat, selambat-lambatnya dalam waktu 14 (empat belas) hari sejak ditandatangani kesepakatan kerja tertentu.

c) Biaya yang timbul akibat pembuatan kesepakatan kerja tertentu semuanya ditanggung oleh pengusaha. ${ }^{13}$

Namun, perlu ditekankan juga bahwa dalam keadaan memaksa yang perlu dikedepankan adalah kebijaksanaan dari para pihak dalam menyikapi kondisi tersebut. Masing-masing pihak harus menyadari secara bijaksana bahwa ada halhal lain yang dapat dikedepankan seperti menanggung kerugian secara bersama atas kerugian yang dialami oleh salah satu pihak. Atau jika keadaan memaksa tersebut membuat salah satu pihak terhambat menjalankan kewajibannya agar pihak lainnya dapat memberikan kebijaksanaan berupa kompensasi pada counterpartnya untuk menjalankan kewajibannya pada waktu lain yang disepakati bersama.

Force majeure merupakan salah satu klausa yang lazimnya berada dalam suatu perjanjian, dikatakan salah satu klausa karena kedudukan force majeure dalam suatu perjanjian berada di dalam perjanjian pokok, tidak terpisah sebagai perjanjian tambahan dan dikaitkan dengan perjanjian pokok selayaknya perjanjian accesoir. Force majeure atau yang sering diterjemahkan sebagai "keadaan memaksa" merupakan keadaan dimana seorang debitur terhalang untuk melaksanakan prestasinya karena keadaan atau peristiwa yang tidak terduga pada saat dibuatnya kontrak, keadaan atau peristiwa tersebut tidak dapat dipertanggungjawabkan kepada debitur, sementara si debitur tersebut tidak dalam keadaan beriktikad buruk.

${ }^{13}$ Muhammad Irvan Hafid, Perlindungan Hukum Terhadap Pekerja Dalam Perjanjian Kerja Waktu Tertentu Berdasarkan Undang-Undang Nomor 13 Tahun 2003 Tentang Ketenagakerjaan (Studi Dinas Ketenagakerjaan Kota Makassar), Jurnal Al Hikmah Volume Xxi Nomor 2/2019, hal 15 
Force majeure tidak bisa secara serta merta dijadikan alasan pembatalan kontrak juga dalam arti pembatalan kontrak dengan alasan force majeure tergantung pada isi klausul kontraknya. Artinya harus dilihat dulu apakah di dalam klausul kontrak tersebut ada kesepakatan bahwa jika terjadi force majeure isi kontrak bisa disimpangi. Jadi harus ada klausul dalam kesepakatan itu. Adapun macam-macam keadaan memaksa, yaitu: keadaan memaksa yang absolut (absolut onmogelijkheid) dan keadaan memaksa yang relatif (relatieve onmogelijkheid).

\section{b. Force Majeure absolut}

Force majeure absolut adalah kejadian yang secara mutlak meniadakan kemampuan pihak untuk memenuhi prestasinya seperti musnahnya bangunan yang dijadikan jaminan kontrak karena bencana alam yang menyebabkannya ambles dan hilang seperti gempa yang terjadi di Palu pada Tahun 2018 yang menyebabkan adanya rumah-rumah dan hotel berbintang lenyap ditelan bumi. ${ }^{14}$

\section{c. Force Majeure relatif}

Force majeure relatif adalah force majeure yang mengubah keadaan tetapi masih ada alternatif-alternatif yang dapat disubstitusikan, dikompensasi, ditunda, dan sebagainya seperti terhalangnya penyampaian barang karena alat transportasi yang membawanya mengalami kecelakaan. ${ }^{15}$

Dari kedua bagian Force Majeure kita berada pada Force Majeure absolut, karena Covid-19 mencakup keadaan memaksa yang bersifat mutlak, yakni membuat para pihak tidak memungkinkan melaksanakan hak dan kewajibannya. Sehingga karyawan yang sebatas pekerja dalam waktu tertentu tidak diberikan secara utuh bahkan tidak diberikan kewajibannya oleh debitur dalam keadaan memaksa seperti pandemic-19 ini.

\section{Perlindungan Hukum Terhadap Pekerja atas Perjanjian Kerja Waktu Tertentu pada Masa Pandemic}

Perlindungan Hukum tenaga kerja sebagaimana yang telah diatur dalam UU 13/2003 bertujuan untuk menjamin berlangsungnya hubungan kerja yang harmonis antara pekerja/buruh dengan pengusaha tanpa disertai adanya tekanan-tekanan dari pihak yang kuat kepada pihak yang lemah. Oleh karena itu pengusaha yang secara sosio-ekonomi memiliki kedudukan yang kuat wajib membantu melaksanakan ketentuan perlindungan tersebut sesuai dengan peraturan perundang-undangan yang berlaku. ${ }^{16}$

"Hukum menentukan kepentingan-kepentingan masyarakat yang dapat ditingkatkan menjadi hak-hak hukum yang dapat dipaksakan pemenuhannya. Hak diberikan kepada pendukung hak yang sering dikenal dengan identitas hukum yang dapat berupa orang perorangan secara kodrati dan dapat juga entitas hukum nir kodrati yaitu entitas hukum atas hasil rekaan hukum". ${ }^{17}$ Terkait perlindungan

${ }^{14}$ Op.Cit, Bahan Seminar Menkopolhukam

${ }^{15}$ Ibid

${ }^{16}$ Rosyita, Ita, et al.Perlindungan Hukum Terhadap Tenaga Kerja Dalam Perjanjian Kerja Waktu Tertentu Pada Perusahaan Garmen, Jurnal Living Law, ISSN 2087-4936 Volume 8 Nomor 2, Oktober 2016, hlm.. 121.

${ }^{17}$ Harjono, 2008, Konstitusi Sebagai Rumah Bangsa, Penerbit Sekretaris Jenderal Dan Kepaniteraan Mahkamah Konstitusi. hal. 377. 
hukum, Philipus M Hadjon"18 "mengatakan bahwa Selalu berkaitan dengan kekuasaan. Ada dua kekuasaan yang selalu menjadi perhatian yakni kekuasaan pemerintah dan kekuasaan ekonomi. Dalam hubungan dengan kekuasaan pemerintah, permasalahan perlindungan hukum bagi rakyat (yang diperintah), terhadap pemerintah (yang memerintah). Dalam hubungan dengan kekuasaan ekonomi, permasalahan perlindungan hukum adalah perlindungan bagi silemah (ekonomi) terhadap si kuat (ekonomi), misalnya perlindungan bagi pekerja terhadap pengusaha".

Perlindungan hukum adalah segala upaya pemenuhan hak dan pemberian bantuan untuk memberikan rasa aman kepada saksi dan/atau korban, perlindungan hukum korban kejahatan sebagai bagian dari perlindungan masyarakat, dapat diwujudkan dalam berbagai bentuk, seperti melalui pemberian restitusi, kompensasi, pelayanan medis, dan bantuan hukum. ${ }^{19}$ Perlindungan hukum yang diberikan kepada subyek hukum ke dalam bentuk perangkat baik yang bersifat preventif maupun yang bersifat represif, baik yang lisan maupun yang tertulis. Dengan kata lain dapat dikatakan bahwa perlindungan hukum sebagai suatu gambaran tersendiri dari fungsi hukum itu sendiri, yang memiliki konsep bahwa hukum memberikan suatu keadilan, ketertiban, kepastian, kemanfaatan dan kedamaian. Pengertian di atas mengundang beberapa ahli untuk mengungkapkan pendapatnya mengenai pengertian dari perlindungan hukum diantaranya: Menurut Satjipto Raharjo mendefinisikan perlindungan hukum adalah memberikan pengayoman kepada hak asasi manusia yang dirugikan orang lain dan perlindungan tersebut diberikan kepada masyarakat agar mereka dapat menikmati semua hak-hak yang diberikan oleh hukum. ${ }^{20}$

Pada 17 Maret 2020 telah ditetapkan Surat Edaran Menteri Ketenagakerjaan Nomor M/3/HK.04/III/2020 Tahun 2020 tentang Perlindungan Pekerja/Buruh dan Kelangsungan Usaha dalam Rangka Pencegahan dan Penanggulangan COVID19 (“SE Menaker 3/2020”).SE Menaker 3/2020 dikeluarkan sehubungan dengan meningkatnya penyebaran COVID-19 di beberapa wilayah Indonesia dan memperhatikan pernyataan resmi World Health Organization (WHO) yang menyatakan COVID-19 sebagai pandemi global. Salah satu hal yang diatur dalam SE Menaker 3/2020 adalah tentang pelaksanakan:

a. bagi pekerja/buruh yang dikategorikan sebagai Orang Dalam Pemantauan (ODP) COVID-19 berdasarkan keterangan dokter sehingga tidak dapat masuk kerja paling lama 14 hari atau sesuai standar Kementerian Kesehatan, maka upahnya dibayarkan secara penuh.

b. Bagi pekerja/buruh yang dikategorikan kasus suspek COVID-19 dan dikarantina/diisolasi menurut keterangan dokter, maka upahnya dibayarkan secara penuh selama menjalani masa karantina/isolasi.

\footnotetext{
${ }^{18}$ M Hadjon, Philipus. “ Perlindungan Hukum Dalam Negara Hukum Pancasila, Makalah Disampaikan Pada Symposium Tentang Politik, Hak Asasi Dan Pembangunan Hukum Dalam Rangka Dies Natalis Xv/ Lustrum Viii, Universitas Airlangga, 3 November 1994

${ }^{19}$ Soerjono Soekanto, 1984, Pengantar Penelitian Hukum, Ui Press. Jakarta, hal. 133 hlm. 53

${ }^{20}$ Satjipto Rahardjo, 2000. Ilmu Hukum, Citra Aditya Bakti, Cetakan Ke-V, Bandung,
} 
c. Bagi pekerja/buruh yang tidak masuk kerja karena sakit COVID-19 dan dibuktikan dengan keterangan dokter, maka upahnya dibayarkan sesuai peraturan perundang-undangan.

d. Bagi perusahaan yang melakukan pembatasan kegiatan usaha akibat kebijakan pemerintah di daerah masing-masing guna pencegahan dan penanggulangan COVID-19, sehingga menyebabkan sebagian atau seluruh pekerja/buruhnya tidak masuk kerja, dengan mempertimbangkan kelangsungan usaha maka perubahan besaran maupun cara pembayaran upah pekerja/buruh dilakukan sesuai dengan kesepakatan antara pengusaha dengan pekerja/buruh.

Jadi dengan mempertimbangkan kelangsungan usaha, perubahan besaran dan cara pembayaran upah pekerja dilakukan sesuai dengan kesepakatan antara pengusaha dengan pekerja. ${ }^{21}$

Berdasarkan SE Menaker 3/2020 juga diatur berbagai pencegahan penyebaran dan penanganan kasus terkait COVID-19 di lingkungan kerja, dengan:

a. melakukan pembinaan dan pengawasan terhadap dilaksanakannya peraturan perundangan di bidang keselamatan dan kesehatan kerja ("K3").

b. menyebarkan informasi kepada semua jajaran organisasi dan pihak terkait yang berada dalam wilayah pembinaan dan pengawasan Gubernur.

c. mendata dan melaporkan kepada instansi terkait setiap kasus atau yang patut diduga kasus COVID-19 di tempat kerja;

d. memerintahkan setiap pimpinan perusahaan untuk melakukan antisipasi penyebaran COVID-19 pada pekerja/buruh dengan melakukan tindakantindakan pencegahan seperti perilaku hidup bersih dan sehat dengan mengintegrasikan dalam program K3, pemberdayaan Panitia Pembina Keselamatan dan Kesehatan Kerja (P2K3) dan optimalisasi fungsi pelayanan kesehatan kerja.

e. mendorong setiap pimpinan perusahaan untuk segera membuat rencana kesiapsiagaan dalam menghadapi pandemi COVID-19, dengan tujuan memperkecil risiko penularan di tempat kerja dan menjaga kelangsungan usaha.

f. dalam hal terdapat pekerja/buruh atau pengusaha yang berisiko, diduga, atau mengalami sakit akibat COVID-19, maka dilakukan langkah-langkah penanganan sesuai standar kesehatan yang dikeluarkan oleh Kementerian Kesehatan. ${ }^{22}$

Perlindungan hukum adalah suatu perlindungan yang diberikan terhadap subjek hukum. Pengertian perlindungan hukum adalah suatu perlindungan yang diberikan terhadap subjek hukum dalam bentuk perangkat hukum baik yang bersifat preventif maupun yang bersifat represif, baik yang tertulis maupun tidak tertulis. Dengan kata lain perlindungan hukum sebagai suatu gambaran dari fungsi hukum

21Keadaan Memaksa/Force Majeur,

Https://Www.Hukumonline.Com/Klinik/Detail/Ulasan/C12572/Keadaan-Memaksa--ForceMajeur/, Diakses Pada 12 Mei 2020.

${ }^{22}$ Faq Bekerja di Tengah Pandemi Corona, Https://Gajimu.Com/Tips-Karir/Kondisi-KerjaDan-Kehidupan-Di-Tengah-Pandemi-Covid-19-Indonesia/Faq-Ketenagakerjaan-Dan-Covid19/Faq-Bekerja-Di-Tengah-Pandemi-Covid-19, Di Akses Pada 12 Mei 2020 
yaitu konsep dimana hukum dapat memberikan suatu keadilan, ketertiban, kepastian, kemanfaatan dan kedamaian. ${ }^{23}$

"Sebagaimana perjanjian kerja pada umumnya, perjanjian kerja waktu tertentu (PKWT) harus memenuhi syarat-syarat pembuatan, baik syarat materil maupun formil. Dalam Undang-Undang Nomor 13 Tahun 2003 syarat materil diatur dalam Pasal 52, Pasal 55, Pasal 58, Pasal 59, dan Pasal 60, sedangkan syarat formil diatur dalam Pasal 54 dan Pasal 57. Seperti dalam Pasal 58 ayat 1 Undang-Undang Nomer 13 Tahun 2003 diatur bahwa PKWT tidak dapat mensyaratkan adanya masa percobaaan kerja. Jadi, jika ada PKWT yang mensyaratkan masa percobaan, maka masa percobaan dalam PKWT tersebut batal demi hukum. Akibat hukumnya PKWT tersebut menjadi PKWTT".

"Syarat-syarat kerja yang dimuat dalam PKWT tidak boleh lebih rendah dari syarat-syarat kerja yang termuat dalam peraturan perusahaan atau perjanjian kerja bersama. Perjanjian kerja waktu tertentu dibuat dalam dua rangkap untuk masing-masing pengusaha dan pekerja/buruh. Mengingat perlunya pencatatan PKWT sebagaimna diatur dalam Pasal 13 Keputusan Menteri Tenaga Kerja dan Transmigrasi Nomor Kep. 100/Men/VI/2004, maka ditambah satu rangkap lagi yaitu untuk instansi yang bertanggung jawab dibidang Ketenagakerjaan Kabupaten/Kota setempat. Pencatatan dilakukan selambat-lambatnya tujuh hari kerja sejak penandatanganan perjanjian kerja. Segala hal dan/atau biaya yang timbul atas pembuatan PKWT menjadi tanggung jawab pengusaha (Pasal 53 Undang-Undang No. 13 Tahun 2003"). ${ }^{24}$

Dalam melakukan pekerjaan tentunya karyawan terlebih dahulu membuat perjanjian, dalam perjanjian biasanya karyawan yang sebagai PKWT berjanji secara lisan, berbeda dengan PKWTT yang kontrak perjanjiannya tersebut di lakukan secara tertulis. Dapat kita lihat bagaimana model-model perjanjian secara peraturan perundang-undangan, diantaranya:

\section{a. Perjanjian Kerja}

Definisi perjanjian kerja dalam Pasal 1 ayat 14 Undang-Undang Nomor 13 Tahun 2003 tentang Ketenagakerjaan adalah perjanjian antara pekerja/buruh dengan mengusaha atau pemberi kerja yang memuat syarat-syarat kerja, hak dan kewajiban para pihak. ${ }^{25}$ Sedangkan Pasal 1601 huruf a KUHPerdata, bahwa yang dimaksud perjanjian perburuhan adalah perjanjian yang dibuat oleh seorang atau beberapa orang majikan atau beberapa perkumpulan majikan yang berbadan hukum dengan suatu atau beberapa serikat buruh yang berbadan hukum mengenai syaratsyarat kerja yang diindahkan pada waktu membuat perjanjian kerja.

\footnotetext{
${ }^{23}$ Rahayu, Pengangkutan Orang, Etd.Eprints.Ums.Ac.Id. Peraturan Pemerintah Ri, Nomor 2 Tahun 2002 Tentang Tata Cara Perlindungan Korban Dan Saksi Dalam Pelanggaran Hak Asasi Manusia Yang Berat,.2009, hlm. 109.

${ }^{24}$ Ibid.

${ }^{25}$ Lihat Pasal 1 Ayat 14 Undang-Undang Nomor 13 Tahun 2003 tentang Ketenagakerjaan.
} 


\section{b. Syarat-syarat perjanjian}

Syarat sahnya perjanjian kerja sebagai bagian dari perjanjian pada umumnya, maka perjanjian kerja harus memenuhi syarat sahnya perjanjian yaitu:

a. kesepakatan kedua belah pihak

b. kemampuan atau kecakapan melakukan perbuatan hukum

c. adanya pekerjaan yang diperjanjikan

d. pekerjaan yang diperjanjikan tidak bertentangan dengan ketertiban umum, kesusilaan dan peraturan perundang-undangan yang berlaku.

Pasal 1338 KUHPerdata juga saling berkaitan dengan perjanjian. Suatu perjanjian tidak dapat ditarik kembali selain dengan kesepakatan kedua belah pihak, atau karena alasan-alasan yang dinyatakan dalam undang-undang dinyatakan cukup untuk itu dan suatu perjanjian harus dilaksanakan dengan itikad baik.

\section{c. Unsur-unsur dalam Perjanjian Kerja}

Unsur-unsur dalam perjanjian kerja Menurut Abdul Khakim ${ }^{26}$ disebutkan bahwa perjanjian kerja dapat ditarik ke dalam beberapa unsur yaitu:

1. Adanya unsur work atau pekerjaan

2. Adanya unsur service atau pelayanan

3. Adanya unsur time atau waktu

4. Adanya unsur upah.

d. Pembagian Perjanjian Kerja

Pasal 1603 e ayat (1) KUHPerdata yang mengatur mengenai perjanjian kerja untuk waktu tertentu. Pekerjaan kerja untuk waktu tertentu juga dibagi menjadi 3 (tiga) yaitu:

1. Pekerjaan untuk waktu tertentu dimana waktu berlakunya ditentukan menurut perjanjian.

2. Pekerjaan untuk waktu tertentu dimana waktu berlakunya ditentukan menurut undang-undang.

3. Pekerjaan untuk waktu tertentu dimana waktu berlakunya ditentukan menurut kebiasaan. $^{27}$

Mengingat kedudukan pekerja yang lebih rendah dari pada majikan/pengusaha maka perlu adanya campur tangan pemerintah untuk memberikan perlindungan hukumnya. Perlindungan hukum yang dimaksud dengan tujuan supaya dalam hubungan kerja dapat terjamin adanya keadilan maupun perlindungan terhadap hak asasi manusia (pekerja) yang keduanya merupakan tujuan dari perlindungan hukum itu sendiri.Dalam hal perjanjian kerja, dapat di bagi lagi menjadi dua, diantaranya:

\section{Perjanjian Kerja untuk Waktu Tidak Tertentu (PKWTT)}

Dalam dunia kerja sering didengar bahwa pekerja tetapmerupakan pekerja dengan ketentuan yang mengacu pada peraturan perundangan di bidang ketenagakerjaan. $^{28}$ (PKWTT) tidak memiliki jangka batas waktu lamanya bekerja selagi pekerja masih dikatakan mampu dan kompeten dalam bidang pekerjaannya. Jika

${ }^{26}$ Abdul Khakim,. 2003. Pengantar Hukum Ketenagakerjaan Di Indonesia. Bandung: Citra Aditya Bakti, hal. 15

${ }^{27}$ Lihat Pasal 1603 E Ayat 1 Kitab Undang-Undang Hukum Perdata

${ }^{28}$ Sudibyo Aji Narendra Buwana, et al. Implementasi Pemutusan Hubungan Kerja (Phk) Terhadap Pekerja Status Perjanjian Kerja Waktu Tertentu (Pkwt) Pada Pt X Di Kota Malang, Universitas Ma Chung, Jurnal Study Manajemen, Vol.9, No 2, Oktober 2015, hal 206 
terjadi Pemutusan Hubungan Kerja (PHK) bukan karena pelanggaran berat atau tenaga kerja mengundurkan diri maka tenaga kerja tetap mendapatkan uang pesangon, uang penghargaan masa kerja (bagi tenaga kerja yang bekerja minimal 3 tahun) dan uang penggantian hak sesuai dengan ketentuan Undang-Undang Ketenagakerjaan yang berlaku. ${ }^{29}$

\section{Perjanjian Kerja Waktu Tertentu}

Tenaga kerja kontrak dipekerjakan oleh perusahaan untuk masa waktu tertentu saja. Hubungan kerja antara perusahaan dan tenaga kerja kontrak dituangkan dalam Perjanjian Kerja Waktu Tertentu. Sesuai ketentuan UU Nomor 13 tahun 2003 tentang Ketenagakerjaan Pasal 62 dinyatakan bahwa apabila salah satu pihak mengakhiri hubungan kerja sebelum berakhirnya jangka waktu yang ditetapkan dalam pekerjaan waktu tertentu, atau berakhirnya berakhirnya hubungan kerja bukan karena terjadinya pelanggaran terhadap ketentuan yang telah disepakati bersama, maka pihak yang mengakhiri hubungan kerja diwajibkan untuk membayar ganti rugi kepada pihak lainnya sebesar upah tenaga kerja sampai batas jangka waktu berakhirnya perjanjian kerja. ${ }^{30}$

Dari apa yang tersebut di atas dapat dikatakan bahwa perjanjian kerja waktu tidak tertentu terjadi karena hal-hal sebagai berikut:

a. PKWT tidak dibuat dalam bahasa Indonesia dan huruf latin.

b. PKWT tidak dibuat untuk pekerjaan yang menurut jenis dan sifat atau kegiatan pekerjaannya akan selesai dalam waktu tertentu, yaitu:

1) Pekerjaan yang sekali selesai atau yang sementara sifatnya.

2) Pekerjaan yang diperkirakan dapat disele-saikan dalam waktu yang tidak terlalu lama, paling lama 3 (tiga) tahun.

3) Pekerjaan yang bersifat musiman.

4) Pekerjaan yang berhubungan dengan produk baru, kegiatan baru, atau produk tambahan yang masih dalam percobaan atau penjajakan,

c. PKWT diadakan untuk untuk pekerjaan yang bersifat tetap.

d. PKWT yang didasarkan atas jangka waktu tertentu diadakan untuk jangka waktu lebih dari 2 tahun dan diperpanjang lebih dari 1 tahun.

e. Pengusaha yang bermaksud memperpanjang PKWT, paling lama7 (tujuh) hari sebelum perjanjian kerja untuk waktu tertentu tersebut berakhir tidak memberikan maksudnya secara tertulis kepada pekerja/buruh yang bersangkutan.

f. Pembaharuan PKWT diadakan tidak melebihi masa tenggang waktu 30 (tigapuluh) hari berakhirnya PKWT yang lama. PKWT diadakan lebih dari 1 (satu) kali dan lebih dari 2 (dua) tahun. ${ }^{31}$

Melihat bagaimana perjainjian kerja terhadap karyawan yang melakukan

Perjanjian Kerja Waktu Tertentu dengan perusahaan, maka sebagai masyarakat kita

29 Abby Tabrani, 2006. Hukum Perburuhan/Ketenagakerjaan Dalam Kumpulan Tulisan Panduan Hukum Indonesia. Edisi Pertama. Jakarta: YLBHI dan PSHK, hlm. 56.

${ }^{30}$ Ibid.

${ }^{31}$ Fithriatus Shalihah, Perjanjian Kerja Waktu Tertentu (PKWT) dalam Hubungan Kerja Menurut Hukum Ketenagakerjaan Indonesia dalam Perspektif HAM, Faculty Of Law, Universitas Islam Riau, UIR Law Review, Volume 01, Nomor 02, Oktober 2017, hlm. 151. 
perlu melakukan revisi terhadap Undang-Undang Ketenaga Kerjaan, dikarenakan hal ini menyebabkan ketidak adilan bagi para pekerja PKWT. Masih banyaknya Warga Negara Indonesia belum mengetahui perbedaan pkwt dan PKWTT sehingga mereka menyamakan kedua hal tersebut. Ketika terjadi Force Majeure seperti saat ini merekalah yang menjadi korban dari ketidak adilan perusahaan dan pemerintah atas hak-haknya yang seharusnya mereka peroleh.

Peraturan yang dikeluarkan oleh Menteri Ketenaga Kerjaan (Menaker) terkait covid, tidak lain hanya kekhawatiran umum masyarakat Indonesia terhadap penularan covid-19, namun terhadap pemutusan, pemecatan terhadap tenaga kerja waktu tertentu tidak diterangkan. Perlunya direvisi kebijakan tersebut secepat mungkin. Walaupun telah ada payung hukum terhadap tenaga kerja dalam sebuah bentuk undang-undang belum bisa menjamin dan memberi rasa keadilan, kemanfaatan hukum itu sendiri. Dalam hubungannya dengan perlindungan hukum, karena tenaga kerja waktu tertentu tidak menerima berbagai tunjangan dan fasilitas sebagaimana yang diterima oleh tenaga kerja waktu tidak tertentu, maka sebaiknya upah yang diberikan kepada tenaga kerja waktu tertentu lebih ditingkatkan. Tidak bisa dipungkiri bahwa hubungan pekerja dan pengusaha adalah simbiosis mutualisme. Pekerja tanpa pengusaha menjadi tidak bermakna apa-apa, sebab pekerja menggantungkan mata pencaharian untuk kelangsungan hidupnya dari pengusaha, sementara pengusaha tanpa pekerja juga tidak berguna sebab proses produksi tidak akan pernah terlaksana tanpa adanya pekerja, oleh karena itu harus disetarakan kedudukan antara PKWT dan PKWTT.

\section{Penutup}

Keadaan memaksa adalah keadaan tidak dipenuhinya prestasi oleh debitur karena terjadi peristiwa yang tidak dapat diketahui atau tidak dapat diduga akan terjadi ketika membuat perikatan. Dalam keadaan memaksa, debitur tidak dapat disalahkan karena keadaan ini timbul di luar kemauan dan kemampuan debitur. Dalam hal foce majeure perusahaan mengambil kesempatan untuk melakukan pemutusan kerja terhadap karyawan dengan alasan debitur tidak mampu membiayai karyawan dengan melihat kondisi penyebaran covid semakin luas.

Dalam hal perlindungan hukum pemrintah telah menetapkan kebijakan dengan cara mengeluarkan Surat Edaran Menteri Ketenagakerjaan Nomor M/3/HK.04/III/2020 Tahun 2020 tentang Perlindungan Pekerja/Buruh dan Kelangsungan Usaha dalam Rangka Pencegahan dan Penanggulangan COVID19 ("SE Menaker 3/2020").Isi dari surat tersebut ialah antara lain mengenai pencegahan penularan Covid-19 saja. Walaupun isinya tidak mampu mengakomodir seluruh kepentingan para karyawan yang telah di PHK. Sehingga dalam konteks ini, sangat perlu perlindungan hukum yang tepat untuk masyarakat Indonesia yang hanya bekerja dengan sebatas waktu tertentu saja. Hal ini sangat sulit bagi mereka dalam memperoleh gaji atau pesangon dari pihak perusahaan.

Tak elok rasanya jika sebuah penelitian tanpa solusi, adapun solusi yang solutif ialah:

1. Melalui pendekatan keadilan persuasif sebagai wujud penegakan hukum yang manusiawi dan berkeadaban. Artinya disini pemerintah dan debitur harus memperbaiki kerugian tersebut dengan cara, mengajak, mengayomi masyarakat 
untuk berpartisipasi membantu masyarakat. Persuasive dapat dilakukan secara emosional biasanya menyentuh aspek afeksi, yaitu berkaitan dengan hal emosional, sehingga para stakeholder yang terlibat dapat bersimpati dan empati terhadap permasalahan force majeure.

2. Memberi kredit kecil mikro untuk pengusaha kecil, agar perusahaan kecil tetap berjalan dengan system pelaksanaan melalui daring, agar pertumbuhan ekonomi tetap stagnan dan mengurangi pengangguran pada masa covid-19.

3. Pada setiap kontrak kerja yang memakai sistem Perjanjian Kerja Waktu Tertentu (PKWT) hendaknya diuraikan secara jelas tentang jenis pekerjaan dan waktu kerja, sehingga terhadap setiap Perjanjian Kerja Waktu Tertentu (PKWT) yang dibuat menjadi jelas bagi pekerja/buruh, atau mengenai pengaturan persyaratan jenis dan sifat pekerjaan yang selama ini diatur oleh pemerintah, hendaknya diserahkan saja kepada kebutuhan para pihak

Buku

\section{DAFTAR PUSTAKA}

Ali, Zainuddin. 2011. Metode Penelitian Hukum. Jakarta: Sinar Grafika. Khakim, Abdul. 2007, Hukum Ketenagakerjaan Indonesia, Pt. Citra Aditia Bakti, Bandung.

Citra Aditya Bakti,

Harjono, Konstitusi Sebagai Rumah Bangsa, 2008, Penerbit: Sekretaris Jenderal Dan Kepaniteraan Mahkamah Konstitusi.

Hariri,Wawan Muhwan. 2011, Hukum Perikatan, Pustaka Setia, Bandung,

Muhammad, Farouk, et al. 2005. Metodologi Penelitian Sosial. Jakarta: Restu Agung.

Rahardjo, Satjipto.2000 Ilmu Hukum, Citra Aditya Bakti, Cetakan Ke-V, Bandung. Soekanto, Soerjono. 1984, Pengantar Penelitian Hukum, UI Press. Jakarta

Dan Sri Mamudji. 2003. Penelitian Hukum Normatif, Suatu

Tinjauan Singkat. Cetakan Keenam. Jakarta: Radagrafindo Persada.

Tabrani, Abby. 2006. Hukum Perburuhan/Ketenagakerjaan Dalam Kumpulan

Tulisan Panduan Hukum Indonesia. Edisi Pertama. Jakarta: YLBHI dan PSHK.

\section{Jurnal/artikel}

Asosiasi Pengajar Hukum Keperdataan,Bencana Covid-19 Dan Pembatalan Kontrak Dalam Bisnis, Perkembangan, Problematik, Dan Implikasi Force Majeure Akibat Covid-19 Bagi Dunia Bisnis" Seminar Nasional Keoordinator Kementeriah Hukum, Politik Dan Keamanan Republik Indonesia.

Buwana, Sudibyo Aji Narendra, et al, Implementasi Pemutusan Hubungan Kerja (Phk) Terhadap Pekerja Status Perjanjian Kerja Waktu Tertentu (Pkwt) Pada Pt X Di Kota Malang, Universitas Ma Chung, Jurnal Study Manajemen, Vol. 9, No 2, Oktober 2015.

Faq Bekerja Di Tengah Pandemi Corona, Https://Gajimu.Com/Tips-Karir/KondisiKerja-Dan-Kehidupan-Di-Tengah-Pandemi-Covid-19-Indonesia/Faq- 
Ketenagakerjaan-Dan-Covid-19/Faq-Bekerja-Di-Tengah-Pandemi-Covid19, Di Akses Pada 12 Mei 2020.

Hafid, Muhammad Irvan. Perlindungan Hukum Terhadap Pekerja Dalam Perjanjian Kerja Waktu Tertentu Berdasarkan Undang-Undang Nomor 13 Tahun 2003

Tentang Ketenagakerjaan (Studi Dinas Ketenagakerjaan Kota Makassar), Jurnal Al Hikmah Volume Xxi Nomor 2/2019.

Indrayani, Kajian Hukum Keterlambatan Membayar (Wanprestasi) Debitur Dalam

Perjanjian Sewa Beli Menurut Aturan Hukum Yang Berlaku, Lex Et Societatis Vol. VII/No. 10/Okt/2019.

Keadaan Memaksa / Force Majeur,

Https://Www.Hukumonline.Com/Klinik/Detail/Ulasan/Cl2572/Keadaan-

Memaksa--Force-Majeur/, Diakses Pada 12 Mei 2020.

Philipus M Hadjon, "Perlindungan Hukum Dalam Negara Hukum Pancasila,

Makalah Disampaikan Pada Symposium Tentang Politik, Hak Asasi Dan

Pembangunan Hukum Dalam Rangka Dies Natalis Xv/ Lustrum Viii,

Universitas Airlangga, 3 November 1994

Rosyita, Ita Dan T.N Syamsah, Perlindungan Hukum Terhadap Tenaga Kerja

Dalam Perjanjian Kerja Waktu Tertentu Pada Perusahaan Garmen Jurnal Living Law Issn 2087-4936 Volume 8 Nomor 2, Oktober 2016.

Rahayu, Pengangkutan Orang, Etd.Eprints.Ums.Ac.Id. Peraturan Pemerintah Ri,

Nomor 2 Tahun 2002 Tentang Tata Cara Perlindungan Korban Dan Saksi

Dalam Pelanggaran Hak Asasi Manusia Yang Berat,. 2009,

Shalihah, Fithriatus.Perjanjian Kerja Waktu Tertentu (Pkwt) Dalam Hubungan Kerja Menurut Hukum Ketenagakerjaan Indonesia Dalam Perspektif Ham, Faculty Of Law, Universitas Islam Riau, Uir Law Review Volume 01, Nomor 02, Oktober 2017.

Simamora, Y. Sogar.Force Majeur Dalam Kontrak Pengadaan Barang/Jasa Pemerintah, makalah seminar nasional, Guru Besar Fh Unair-Surabaya Ketua Asosiasi Pengajar Hukum Keperdataan

Tengku Erwinsyahbana. 2017. "Pertanggungjawaban Yuridis Direksi Terhadap Risiko Kerugian Keuangan Daerah Pada Badan Usaha Milik Daerah". Jurnal Ilmu Hukum De Lega Lata. Vol. 2 No. 1. Januari-Juni. Medan: Fakultas Hukum Universitas Muhammadiyah Sumatera Utara.

Wulandari, Dini Ajeng. 2016, Wanprestasi Debitur Akibat Force Majeure (Bencana Alam) Dalam Perjanjian Kredit (Study Putusan Nomor: 25/Pdt.G/2010/Pn.Smi), Skripsi, Fakultas Hukum, Universitas Jember.

\section{Peraturan Perundang-Undangan}

Undang-Undang Dasar Negara Republik Indonesia (UUD NRI) Tahun 1945

Undang - Undang Nomor 13 Tahun 2003 Tentang Ketenagakerjaan

Surat Edaran Menteri Ketenagakerjaan Nomor M/3/HK.04/III/2020 Tahun 2020 tentang Perlindungan Pekerja/Buruh dan Kelangsungan Usaha dalam Rangka Pencegahan dan Penanggulangan COVID-19 ("SE Menaker 3/2020"). 